\title{
MENINGKATKAN PROSES DAN HASIL BELAJAR RANGKAIAN LISTRIK MELALUI PEMBELAJARAN KOOPERATIF MODEL STAD
}

\author{
Djoko Santoso ${ }^{1}$, Umi Rochayati $^{2}$ \\ ${ }^{1}$ Jurusan Pendidikan Teknik Elektronika FT UNY; Jurusan Pendidikan Teknik Elektronika FT UNY; \\ Email: djokosantoso@uny.ac.id
}

\begin{abstract}
ABSTRAK
Penelitian bertujuan untuk meningkatkan kualitas pembelajaran, hasil belajar serta tanggapan mahasiswa terhadap implementasi pembelajaran kooperatif model STAD. Model penelitian tindakan kelas dengan tiga siklus, dilaksanakan tiga bulan terhadap mahasiswa S1 reguler Jurusan Teknik Elektronika yang mengambil mata kuliah rangkaian listrik. Pegumpulan data dengan dokumentasi, observasi, dan tes, angket. Hasil penelitian menunjukkan pembelajaran kooperatif STAD dapat meningkatkan kualitas pembelajaran. Proses pembelajaran terkesan lebih menarik karena mahasiswa bukan lagi sebagai obyek tetapi lebih sebagai subyek dalam pembelajaran. Kondisi pembelajaran diwarnai dengan aktivitas diskusi kelompok, mahasiswa berperan aktif dan saling ketergantungan satu sama lain dalam penguasaan konsep, sehingga terjadi interaksi belajar multi arah, peran dosen justru sebagai fasilitator. Hasil belajar mahasiswa mengalami peningkatan pada setiap siklusnya. Tanggapan mahasiswa terhadap implementasi pembelajaran kooperatif STAD 10,81 \% menyatakan sangat setuju dan $89,19 \%$ menyatakan setuju.
\end{abstract}

Kata kunci: pembelajaran kooperatif model STAD

\section{PENDAHULUAN}

Perkuliahan mata kuliah rangkaian listrik di Jurusan Pendidikan Teknik Elektronika Fakultas Teknik Universitas Negeri Yogyakarta merupakan bagian dari kerangka dasar proses pemahaman mahasiswa terhadap masalah kelistrikkan. Pengajaran rangkaian listrik pada mahasiswa memberikan suatu tantangan yang besar bagi pengajarnya. Hal ini disebabkan dari sejumlah besar materi rangkaian listrik terdiri dari konsep-konsep yang abstrak.

Fakta dan data menunjukkan bahwa penguasaan mahasiswa di bidang ilmu kelistrikkan terutama pada pemahaman konsep masih rendah dan banyak mengalami berbagai macam kendala.. Ini dapat dipahami karena besaran listrik memang tidak bisa dilihat langsung tanpa bantuan alat ukur (seperti : arus, tegangan, daya, hambatan dsb) tetapi semuanya dapat dirancang, dihitung dan dapat dimanfaatkan. Ditambah lagi selama ini proses pembelajaran yang diterapkan pada perkuliahan rangkaian listrik masih menggunakan metode teacher centered learning dimana peran dosen masih sangat dominan sehingga berdampak pada kurang mandirinya mahasiswa. Gejala ini dapat diamati dari kurangnya interaksi antara mahasiswa dengan dosen apabila ada permasalahan tentang konsep kelistrikan yang dilontarkan dosen ke mahasiswa, mahasiswa cenderung diam. Diam disini dapat diartikan apakah mahasiswa tersebut tidak mengerti atau tidak tahu apa yang harus ditanyakan.

Demikian pula umumnya mahasiswa dalam mempelajarinya tidak terlalu peduli pada hakekat konsep, tetapi yang diutamakan adalah menghitung hasil akhir. Berangkat dari permasalahan ini peneliti mencoba mengubah budaya perkuliahan 
dari teacher centered learning ke student centered learning.

Penelitian ini akan memngungkap : (1) pembelajaran kooperatif model STAD apakah dapat meningkatkan kualitas proses belajar rangkaian listrik pada mahasiswa Jurusan Teknik Elektronika FT UNY, (2) pembelajaran kooperatif model STAD apakah dapat meningkatkan hasil belajar rangkaian listrik pada mahasiswa Jurusan Teknik Elektronika FT UNY, tanggapan mahasiswa Jurusan Teknik Elektronika FT UNY terhadap implementasi pembelajaran kooperatif model STAD pada mata kuliah rangkaian listrik.

Belajar dan mengajar sebagai suatu proses mengandung tiga unsur yang dapat dibedakan, yakni tujuan pengajaran, pengalaman (proses) belajar-mengajar, dan hasil belajar (Nana Sudjana, 2002). Dalam pembelajaran kooperatif mahasiswa belajar dan bekerja dalam kelompok-kelompok kecil terdiri dari tiga sampai empat orang. Sebagaimana dikemukakan Johnson \& Johnson (1987) pembelajaran kooperatif merupakan bentuk pengajaran yang menekankan adanya kerja sama, yaitu kerja sama antar kelompoknya untuk mencapai tujuan belajar. Hal ini dimaksudkan agar interaksi mahasiswa menjadi maksimal dan efektif. Demikian pula Ibrahim (2000) menyatakan mahasiswa yang bekerja dalam situasi pembelajaran kooperatif didorong dan atau dikehendaki untuk bekerjasama pada suatu tugas bersama, dan mereka mengkoordinasikan usahanya untuk menyelesaikan tugasnya. Pembelajaran kooperatif tidak semata-mata meminta mahasiswa bekerja secara kelompok dengan cara mereka sendiri tetapi mereka harus bekerja sama untuk mencapai tujuan bersama. Model pembelajaran ini berpandangan bahwa mahasiswa akan lebih mudah menemukan dan memahami konsep-konsep yang sulit apabila mereka saling mendiskusikan konsep-konsep tersebut dengan teman sebayanya (Slavin, 1994). Pada dasarnya, pengelompokan bukanlah tujuan utama belajar kooperatif. Paulina (2001) menyatakan, belajar kooperatif menuntut adanya modifikasi tujuan pembelajaran dari sekedar penyampaian informasi (transfer of information) menjadi konstruksi pengetahuan (construction of knowledge) oleh individu mahasiswa melalui belajar kelompok

$$
\text { Lebih lanjut Slavin (1994) }
$$

menyatakan beberapa bentuk pembelajaran kooperatif meliputi : Student Teams Achievement Divisions (STAD), Jigsaw II, Teams Games-Tournaments (TGT). Paulina (2001) mengatakan STAD terdiri dari empat langkah, yaitu : sajian dosen, diskusi kelompok mahasiswa, tes/kuis silang tanya antar kelompok, dan penguatan dari dosen. Sajian dosen meliputi penyajian pokok permasalahan, kaidah, dan prinsip-prinsip bidang ilmu. Penyajian dosen dalam bentuk ceramah, tanya jawab. Diskusi kelompok dilakukan berdasarkan permasalahan yang disampaikan oleh dosen, oleh sekelompok mahasiswa yang cukup heterogen. Peran dosen sangat diperlukan untuk mengatasi konflik antar anggota kelompok. Diskusi kelompok merupakan komponen yang paling penting, karena sangat berperan dalam aktualisasi kelompok secara sinergis untuk mencapai hasil yang terbaik, dan pembimbingan antar anggota kelompok sehingga seluruh anggota kelompok sebagai satu kesatuan dapat mencapai yang terbaik. Setelah pendalaman materi, 
dilakukan tes/kuis atau silang tanya antar kelompok mahasiswa untuk mengetahui hasil belajar mahasiswa, sementara dosen memberikan penguatan dalam dialog tersebut. Dalam pelaksanaan pembelajaran kooperatif ada tiga tahap yang dilakukan oleh pengajar, yaitu persiapan, proses belajar, dan evaluasi.

\section{METODE}

Penelitian tindakan kelas ini menggunakan model rancangan penelitian tindakan kelas yang dikembangkan oleh Kemmis dan Mc Taggart (Sudarsono,1997: 20). Pelaksanaanya berlangsung tiga siklus yang disesuaikan dengan alokasi waktu dan pokok bahasan yang dipilih. Tiap siklus terdiri dari 4 kegiatan, yaitu : 1) perencanaan berisi rencana tindakan yang akan dilakukan untuk memperbaiki, meningkatkan atau mengubah perilaku dan sikap sebagai solusi; 2) tindakan berisi kegiatan yang dilakukan peneliti sebagai upaya perbaikan, peningkatan atau perubahan yang diinginkan; 3) observasi, pengamatan atas hasil dari tindakan yang dilakukan; 4) refleksi, peneliti mengkaji, melihat dan mempertimbangkan atas hasil atau dampak dari tindakan yang dilakukan.

Penelitian dilaksanakan di Jurusan Pendidikan Teknik Elektronika FT UNY, pelaksanaannya bulan September November 2008. Subyek penelitian mahasiswa S1 reguler Program Studi Pendidikan Teknik Elektronika yang mengambil mata kuliah rangkaian listrik tahun 2008/2009 sebanyak 37 mahasiswa.

Pegumpulan data dilakukan dengan teknik dokumentasi, observasi, tes, dan angket. Instrumen yang digunakan dalam penelitian meliputi: lembar observasi, tes tertulis, dan angket. Instrumen observasi disusun berdasarkan komponen dasar pembelajaran kooperatif. Tes tertulis digunakan untuk mengetahui kualitas hasil belajar. Soal tes tertulis dilakukan judgment terlebih dahulu pada ahlinya. Angket untuk mengetahui tanggapan mahasiswa terhadap pembelajaran kooperatif, digunakan angket tertutup dan angket terbuka, namun sebelum analisis lebih jauh terlebih dahulu diuji validitas dan reliabilitasnya.

Teknik analisis data adalah kualitatif, ini untuk menggambarkan keterlaksanaan tindakan dalam pelaksanaan pembelajaran dan mendeskripsikan aktivitas mahasiswa dalam kegiatan pembelajaran. untuk analisis respon mahasiswa terhadap pelaksanaan pembelajaran digunakan deskriptif presentase.

\section{HASIL DAN PEMBAHASAN}

Sebelum melakukan tindakan, terlebih dahulu dilakukan diskusi sesama tim peneliti mengenai tata cara pelaksanaan, penetapan materi pembelajaran, waktu, dan menghasilkan kesepahaman mengenai rencana tindakan untuk meningkatkan kualitas pembelajaran rangkaian listrik melalui pembelajaran kooperatif model STAD. Selanjutnya menentukan pokok-pokok yang harus dilakukan dalam menyusun rancangan pembelajaran kooperatif STAD dan menentukan jumlah kelompok, masingmasing anggota kelompok harus bersifat heterogen dilihat dari segi kemampuan akademiknya.

$$
\text { Siklus I dengan materi : }
$$

Pengertian listrik DC, Resistansi, kapasitansi, Induktansi, (2)Hukum Ohm, Hukum Kirchoff I dan II. Dilakukan sebanyak 2 kali pertemuan setiap pertemuan kegiatan pembelajaran lebih diorientasikan pada peran mahasiswa aktif dalam belajar. Pelaksanaan tindakan, 
peneliti melakukan penyelenggaran PBM dan observasi dengan mencatat apa saja yang diamati saat proses pembelajaran berlangsung sesuai poin-poin yang telah tersedia dalam lembar observasi.

Hasil pengamatan siklus I pertemuan pertama, mahasiswa dalam mengerjakan tugas kelompok belum kompak, mereka dalam mengerjakan tugas masih didominasi secara individu, argumentasipun belum begitu nampak.
Tetapi konsentrasi dalam mengikuti PBM tinggi, mengerjakan tugas baik, dan menghargai pendapat mahasiswa lain juga baik. Tetapi bertanya, merespon pertanyaan, dan memberikan pendapat untuk pemecahan masalah masih belum menggembirakan. Hasil tabulasinya terlihat pada tabel 1 .

Tabel 1. Hasil Pengamatan Kegiatan Mahasiswa dalam PBM Siklus I

\begin{tabular}{lcccc}
\hline \multirow{2}{*}{ Aspek Pengamatan } & \multicolumn{3}{c}{ Pertemuan $\boldsymbol{k e -}$} \\
\cline { 2 - 5 } & \multicolumn{1}{c}{$\mathbf{1}$} & $\mathbf{2}$ \\
\cline { 2 - 5 } & $\mathbf{J m l}$ & $\mathbf{\%}$ & $\mathbf{J m l}$ & 91,89 \\
\hline Perhatian/konsentrasi dalam mengikuti PBM & 33 & 91,66 & 34 & 18,92 \\
\hline Mengajukan pertanyaan & 5 & 13,51 & 7 & 16,22 \\
\hline Merespon pertanyaan & 4 & 11,11 & 6 & 27,03 \\
\hline Memberikan pendapat untuk pemecahan masalah & 12 & 33,33 & 10 & 94,59 \\
\hline Menghargai pendapat mahasiswa lain & 32 & 88,88 & 35 & 100 \\
\hline Mengerjakan tugas & 36 & 100 & 37 & 81,08 \\
\hline Kerjasama & 24 & 66,67 & 30 & 100 \\
\hline Jumlah mahasiswa yang hadir & 36 & 97,30 & 37 & 37
\end{tabular}

Pertemuan kedua mahasiswa mulai terlihat antusias dan termotivasi dalam mengerjakan tugas. Tetapi saat mulai melaksanakan diskusi masih ada beberapa mahasiswa yang santai dan bekerja sendiri. Dari beberapa poin yang diamati semuanya terjadi peningkatan, argumentasi sudah mulai tampak, dominasi individu mulai berkurang, mendorong anggota kelompok untuk memberikan kontribusi dalam memecahkan permasalahan mulai berkembang dan pembelajaran tampak hidup.
Disamping perilaku yang diamati saat belajar teori, pengamatan juga dilakukan pada kegiatan praktikum, dari dua kali pertemuan kegiatan hasilnya ditunjukkan pada tabel 2. Dari tabel tampak bahwa dari pertemuan ke pertemuan terjadi peningkatan kualitas pelaksanaan praktikum. Hal yang masih perlu ditingkatkan terutama dalam mengenal nama alat ukur, membedakan skala, batas ukur, kegunaan alat ukur, spesifikasi, membaca besaran harga bahan-bahan praktikum pada komponen kapasitor dalam setiap percobaan dan kecermatan dalam 
pembacaan data percobaan. Ini dapat hal baru, maka banyak diperlukan dimaklumi kenyataan melaksanakan praktikum laboratorium bagi mereka yang penyesuaian baik sikap maupun dari SMA maupun MAN masih merupakan penggunaan peralatan praktikum.

Tabel 2. Rangkuman Penilaian Pelaksanaan Praktikum Kelompok

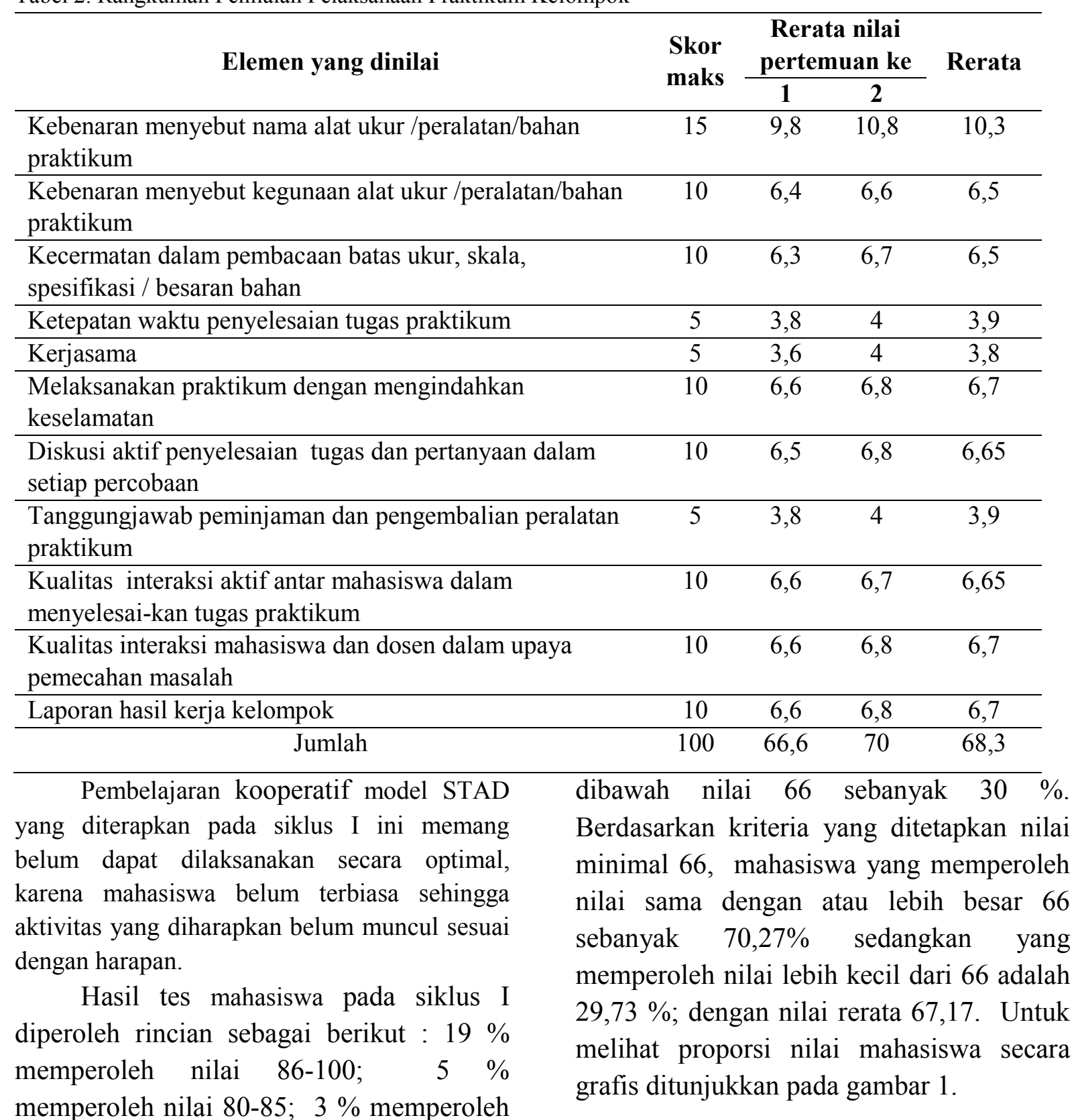
nilai $75-79 ; 13 \%$ memperoleh nilai $71-74$, $30 \%$ memperoleh nilai $66-70$ dan 


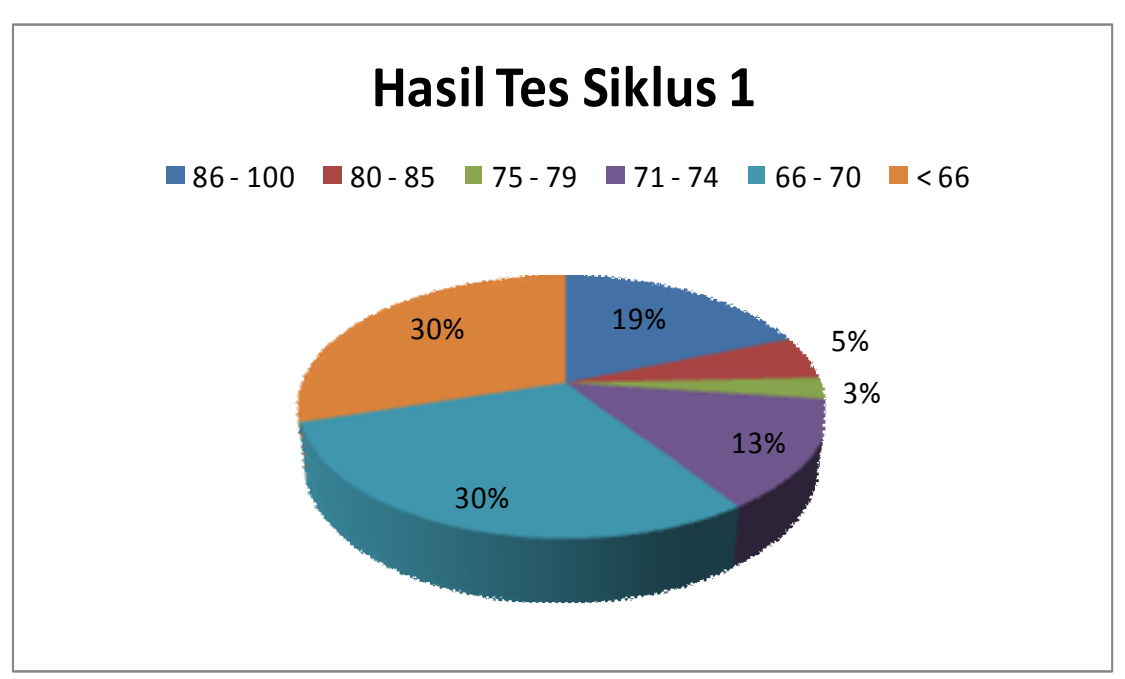

Gambar 1. Proporsi nilai mahasiswa pada siklus I

Siklus II merupakan kelanjutan siklus I, karena pelaksanaan pembelajaran siklus I belum sesuai dengan harapan. Siklus II pelakasanaanya juga dua kali pertemuan, setiap pertemuan kegiatan pembelajaran lebih diorientasikan pada peran aktif mahasiswa dalam belajar. Pelaksanaan tindakan, peneliti melakukan penyelenggaran PBM dan observasi dengan mencatat apa saja yang diamati saat proses pembelajaran berlangsung sesuai poinpoin yang telah tersedia dalam lembar observasi. Materi siklus II meliputi : (1) Rangkaian tahanan dihubung seri, paralel, campuran, (2) Transformasi segitiga-bintang dan bintang-segitiga.

Dalam pelaksanaan perkuliahan dosen menyampaikan kompetensi pembelajaran dilanjutkan dengan menjelaskan materi pelajaran dan diikuti tanya jawab. Selanjutnya meminta mahasiswa untuk memasuki kelompoknya masing-masing. Langkah berikutnya dosen memberikan kasus/tugas kepada masingmasing mahasiswa dalam kelompok ; tugas tersebut dikerjakan secara diskusi oleh masing-masing kelompok dibawah bimbingan dosen dengan waktu yang sudah ditentukan. Dalam proses tersebut peneliti bersama tim memgamati sekaligus membimbing kerjasama dalam kelompok.

Hasil pengamatan pembelajaran siklus II, secara keseluruhan mahasiswa sudah mulai menyesuaikan dengan model pembelajaran yang dilakukan. Adanya beberapa perbaikan rencana pembelajaran menampakkan hasil yang menggembirakan, yaitu dengan mempelajari materi yang akan dibahas mahasiswa lebih siap berdiskusi. Demikian pula dengan tugas yang kompleks membuat mahasiswa lebih serius dalam diskusi. Pertemuan pertama, dalam mengerjakan tugas kelompok mulai kompak, bertanya dan merespon pertanyaan juga meningkat dibandingkan pertemuan sebelumnya, dominasi mahasiswa terhadap pemecahan masalah semakin berkurang, diskusi kelompok mulai menggembirakan.

Pertemuan kedua proses pembelajaran lebih santai, mahasiswa yang mau bertanya lebih banyak, diskusi sesama teman maupun bertanya pada dosen semakin berani. Kondisi diskusi semakin hidup akibat mereka telah menyiapkan materi lebih dahulu. Hasil pengamatan yang dilakukan pada saat perkuliahan ditunjukkan tabel 3 
Tabel 3. Hasil Pengamatan Kegiatan Mahasiswa dalam PBM Siklus II

\begin{tabular}{lcccc}
\hline \multirow{2}{*}{\multicolumn{1}{c}{ Aspek Pengamatan }} & \multicolumn{4}{c}{ Pertemuan ke- } \\
\cline { 2 - 5 } & \multicolumn{3}{c}{$\mathbf{1}$} & $\mathbf{2}$ \\
\cline { 2 - 5 } & Jml & $\mathbf{\%}$ & Jml & $\mathbf{\%}$ \\
\hline Perhatian/konsentrasi dalam mengikuti PBM & 37 & 100 & 37 & 100 \\
\hline Mengajukan pertanyaan & 7 & 18,92 & 8 & 21,62 \\
\hline Merespon pertanyaan & 6 & 16,22 & 7 & 18,92 \\
\hline Memberikan pendapat untuk pemecahan masalah & 16 & 43,24 & 15 & 40,54 \\
\hline Menghargai pendapat mahasiswa lain & 34 & 91,89 & 36 & 97,29 \\
\hline Mengerjakan tugas & 37 & 100 & 37 & 100 \\
\hline Kerjasama & 37 & 100 & 37 & 100 \\
\hline Jumlah mahasiswa yang hadir & 37 & 100 & 37 & 100 \\
\hline Jumlah & mahasiswa & keseluruhan &
\end{tabular}

Pengamatan pada kegiatan praktikum, dari kedua kali pertemuan kegiatan hasilnya ditabulasikan pada tabel 4. Dari tabel tampak bahwa dari pertemuan ke pertemuan terjadi peningkatan kualitas pelaksanaan praktikum. Hal yang masih perlu ditingkatkan adalah tentang kebenaran dan kerapian terutama berkaitan dengan warna kabel/kawat penghubung yang membedakan antara positip dan negatip atau phasa dan nol, mengoperasikan peralatan, dan kecermatan dalam pembacaan data percobaan. Ini dapat dimengerti karena pada job yang ketiga dan keempat karakteristiknya berbeda dengan job pertama dan kedua. Job pertama dan kedua sifatnya baru mengenal nama,jenis, batas ukur skala, kegunaan,dan spesifikasinya, sedangkan job tiga dan empat sudah mulai membuat rangkaian, memasang alat ukur, beban, membaca berbagai macam alat ukur. Oleh karena itu mahasiswa masih perlu menyesuaikan dan mencermati dalam menggunakan peralatan praktikum dalam merangkai rangkaian percobaan

Tabel 4. Rangkuman Penilaian Pelaksanaan Praktikum Kelompok

\begin{tabular}{|c|c|c|c|c|}
\hline \multirow{2}{*}{ Elemen yang dinilai } & \multirow{2}{*}{$\begin{array}{l}\text { Skor } \\
\text { maks }\end{array}$} & \multicolumn{2}{|c|}{$\begin{array}{c}\text { Rerata nilai } \\
\text { pertemuan ke }\end{array}$} & \multirow{2}{*}{ Rerata } \\
\hline & & 1 & 2 & \\
\hline Kebenaran dan kerapihan penyusunan rangkaian praktikum & 15 & 9,8 & 106 & 10,2 \\
\hline Kesesuaian dalam mengoperasikan peralatan praktikum dengan prosedur & 10 & 6,6 & 6,8 & 6,7 \\
\hline Kecermatan dalam pembacaan data percobaan & 10 & 6,5 & 6,8 & 6,65 \\
\hline Ketepatan waktu penyelesaian tugas praktikum & 5 & 4,4 & 4,5 & 4,45 \\
\hline Kerjasama & 5 & 4,3 & 4,4 & 4,35 \\
\hline Melaksanakan praktikum dengan mengindahkan keselamatan & 10 & 7 & 7,4 & 7,2 \\
\hline Diskusi aktif penyelesaian tugas dan pertanyaan dalam setiap percobaan & 10 & 7,4 & 7,6 & 7,5 \\
\hline Tanggungjawab peminjaman dan pengembalian peralatan praktikum & 5 & 4,3 & 4,5 & 4,4 \\
\hline $\begin{array}{l}\text { Kualitas interaksi aktif antar mahasiswa dalam menyelesai-kan tugas } \\
\text { praktikum }\end{array}$ & 10 & 7,2 & 7,5 & 7,35 \\
\hline $\begin{array}{l}\text { Kualitas interaksi mahasiswa dan dosen dalam upaya pemecahan } \\
\text { masalah }\end{array}$ & 10 & 7,4 & 7,5 & 7,45 \\
\hline Laporan hasil kerja kelompok & 10 & 7,4 & 7,6 & 7,5 \\
\hline
\end{tabular}




$$
\text { Jumlah }
$$

Berdasarkan hasil refleksi terhadap tindakan yang dilakukan pada siklus II menunjukkan bahwa secara umum telah terjadi peningkatan kualitas pembelajaran pada mata kuliah rangkaian listrik. Kenyataan ini terlihat dari aktivitas mahasiswa yang lebih aktif dalam mengikuti pembelajaran.

Hasil tes mahasiswa pada siklus II diperoleh rincian sebagai berikut : $22 \%$ memperoleh nilai $86-100, \quad 16 \%$ memperoleh nilai $80-85,3 \%$ memperoleh

$100 \quad 72,3 \quad 75,2 \quad 73,75$

nilai $75-79,16 \%$ memperoleh nilai $71-74$, $19 \%$ memperoleh nilai 66-70, dan dibawah nilai 66 sebanyak $24 \%$. Berdasarkan kriteria yang ditetapkan nilai minimal adalah 66, mahasiswa yang mempunyai nilai sama dengan atau lebih besar 66 sejumlah $75,68 \%$ sedangkan yang mempunyai nilai lebih kecil dari 66 adalah $24,32 \%$, dengan nilai rerata 72,28 . Untuk melihat proporsi nilai mahasiswa secara grafis ditunjukkan pada gambar 2 .

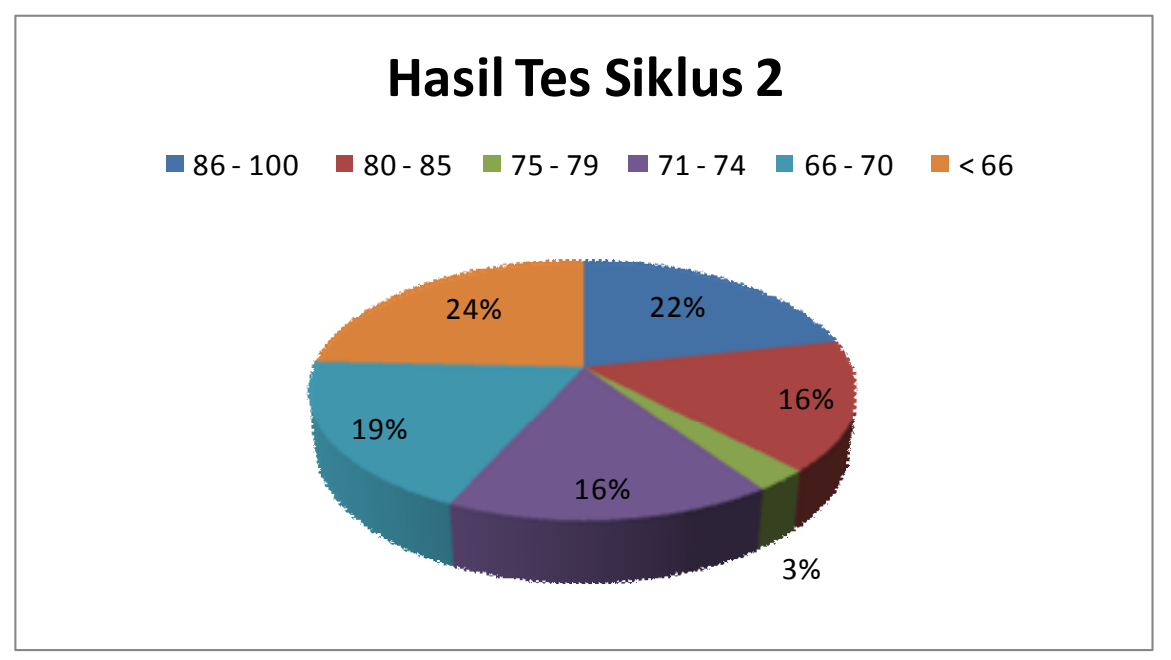

Gambar 2. Proporsi nilai mahasiswa pada siklus II

Siklus III merupakan kelanjutan dari siklus I dan siklus II, dampak pelaksanaan pembelajaran pada siklus II hasilnya sudah sesuai dengan harapan yaitu nilainya lebih besar/sama dengan 66 sudah mencapai 75 $\%$, tetapi masih perlu peningkatan terutama yang berkaitan pelaksanaan praktikum. Walaupun hasil refleksi pada siklus II mulai terlihat kemampuan mahasiswa dari aktivitasnya yang lebih aktif dalam mengikuti pembelajaran.

Pelaksanaan siklus III dilakukan dua kali pertemuan, setiap pertemuan kegiatan pembelajaran lebih diorientasikan pada peran mahasiswa aktif dalam belajar.
Pelaksanaan tindakan, peneliti melakukan penyelenggaran PBM dan observasi dengan mencatat apa saja yang diamati saat proses pembelajaran berlangsung sesuai poin-poin yang telah tersedia dalam lembar observasi. Materi siklus III secara rinci meliputi : (1) Teorema Superposisi, Thevenin, Norton, (2) Pengisian dan Pengosongan Kapasitor dan Induktor.

Pengamatan kegiatan pembelajaran siklus III, mahasiswa semakin tampak mengikuti pembelajaran, mereka mulai terbiasa dengan pembelajaran yang dilakukan. Adanya beberapa perbaikan rencana pembelajaran mulai kelihatan 
hasilnya., yaitu dengan mempelajari job praktikum sekaligus menghitung besaran yang akan dipraktekan mereka jauh lebih siap. Demikian pula sebelum merangkai rangkaian dengan menggunakan alat ukur, alat ukurnya harus diperhatikan batas ukurnya, skalanya, kemampuannya, cara menyambungnya mereka semakin teliti, sehingga jalannya percobaan semakin lancar dan bila terjadi kesalahan hasil mahasiswa mengetahuinya.

Hasil pengamatan yang dilakukan pada saat perkuliahan oleh tim peneliti ditunjukkan pada tabel 5 .

Tabel 5. Hasil Pengamatan Kegiatan Mahasiswa dalam PBM Siklus III

\begin{tabular}{|c|c|c|c|c|}
\hline \multirow{3}{*}{ Aspek Pengamatan } & \multicolumn{4}{|c|}{ Pertemuan ke- } \\
\hline & \multicolumn{2}{|c|}{1} & \multicolumn{2}{|c|}{2} \\
\hline & $\mathbf{J m l}$ & $\%$ & $\mathbf{J m l}$ & $\%$ \\
\hline Perhatian/konsentrasi dalam mengikuti PBM & 37 & 100 & 37 & 100 \\
\hline Mengajukan pertanyaan & 9 & 24,32 & 9 & 24,32 \\
\hline Merespon pertanyaan & 7 & 18,92 & 8 & 21,62 \\
\hline Memberikan pendapat untuk pemecahan masalah & 20 & 54,05 & 22 & 59,46 \\
\hline Menghargai pendapat mahasiswa lain & 37 & 100 & 37 & 100 \\
\hline Mengerjakan tugas & 37 & 100 & 37 & 100 \\
\hline Kerjasama & 37 & 100 & 37 & 100 \\
\hline Jumlah mahasiswa yang hadir & 37 & 100 & 37 & 100 \\
\hline
\end{tabular}

Jumlah mahasiswa keseluruhan 37

Pengamatan pada kegiatan

praktikum, dari dua kali pertemuan

diperoleh hasil pengamatan ditabulasikan

pertemuan ke pertemuan berikutnya terjadi pada tabel 6. Dari tabel tampak bahwa dari peningkatan kualitas pelaksanaan praktikum.

Tabel 6. Rangkuman Penilaian Pelaksanaan Praktikum Kelompok

\begin{tabular}{lcccc}
\hline \multicolumn{1}{c}{ Elemen yang dinilai } & Skor & \multicolumn{2}{c}{$\begin{array}{c}\text { Rerata nilai } \\
\text { pertemuan ke }\end{array}$} & \multirow{2}{*}{ Rerata } \\
\cline { 3 - 4 } & & $\mathbf{1}$ & $\mathbf{2}$ & \\
\hline Kebenaran dan kerapihan penyusunan rangkaian praktik & 15 & 11,2 & 12 & 11,6 \\
\hline Kesesuaian dalam mengoperasikan peralatan praktikum dengan prosedur & 10 & 7,2 & 7,5 & 7,35 \\
\hline Kecermatan dalam pembacaan data percobaan & 10 & 7,4 & 7,6 & 7,5 \\
\hline Ketepatan waktu penyelesaian tugas praktikum & 5 & 4,5 & 4,6 & 4,55 \\
\hline Kerjasama & 5 & 4,5 & 4,7 & 4,6 \\
\hline Melaksanakan praktikum dengan mengindahkan keselamatan & 10 & 7,7 & 7,9 & 7,8 \\
\hline Diskusi aktif penyelesaian tugas dan pertanyaan dalam setiap percobaan & 10 & 7,6 & 8 & 7,8 \\
\hline Tanggungjawab peminjaman dan pengembalian peralatan praktikum & 5 & 4,2 & 4,5 & 4,35 \\
\hline $\begin{array}{l}\text { Kualitas interaksi aktif antar mahasiswa dalam menyelesai-kan tugas } \\
\text { praktikum }\end{array}$ & 10 & 7,7 & 8 & 7,85 \\
\hline Kualitas interaksi mahasiswa dan dosen dalam upaya pemecahan masalah & 10 & 7,6 & 7,8 & 7,7 \\
\hline Laporan hasil kerja kelompok & 10 & 7,8 & 8,1 & 7,95 \\
\hline
\end{tabular}


Hasil tes mahasiswa pada siklus III diperoleh rincian sebagai berikut : $22 \%$ memperoleh nilai 86-100, $13 \%$ memperoleh nilai 80-85, $11 \%$ memperoleh nilai $75-79,19 \%$ memperoleh nilai 71-74, $16 \%$ memperoleh nilai $66-70$, dan dibawah nilai 66 sebanyak $19 \%$. Berdasarkan kriteria yang ditetapkan nilai minimal adalah 66, mahasiswa yang mempunyai nilai sama dengan atau lebih besar 66 sejumlah $81 \%$ sedangkan yang mempunyai nilai lebih kecil dari 66 adalah $19 \%$, dengan nilai rerata 74,93 . Untuk melihat proporsi nilai mahasiswa secara grafis ditunjukkan pada gambar 3 .

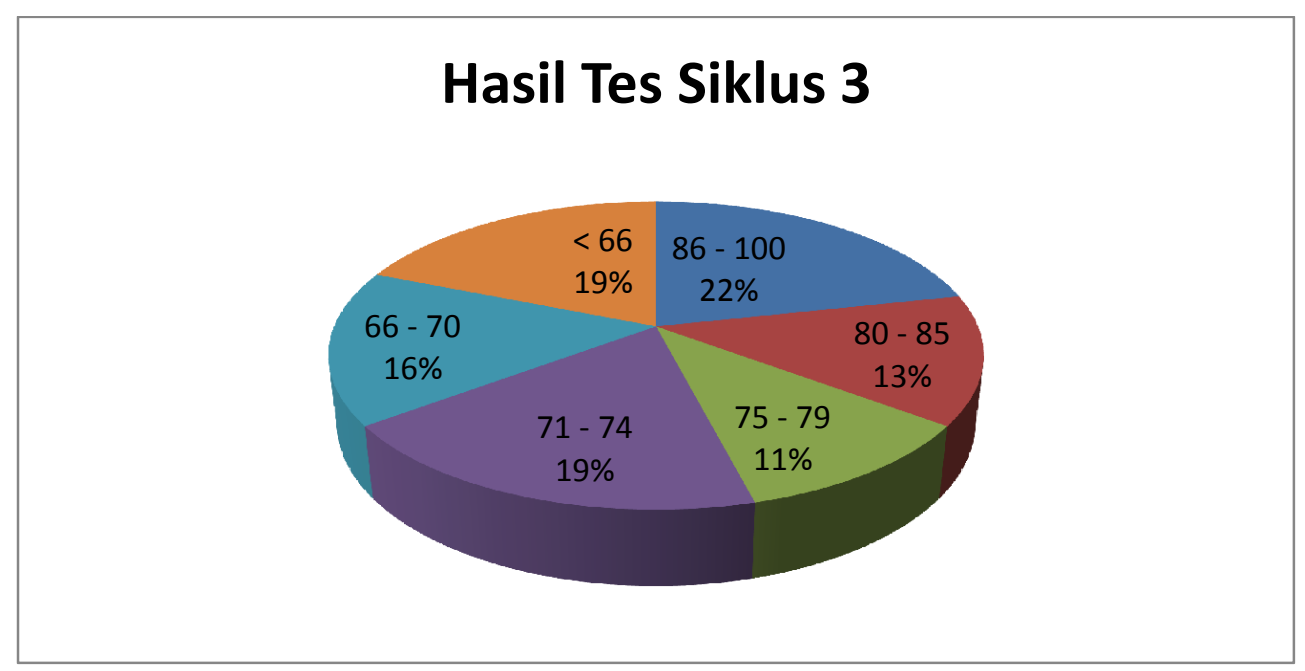

Gambar 3. Proporsi nilai mahasiswa pada siklus III

Berdasarkan hasil observasi dan data diperoleh siklus III sudah menunjukkan peningkatan kualitas pembelajaran dan hasil belajar dibandingkan dengan siklus II, hasil tes nilainya sudah memenuhi kriteria, yaitu lebih dari $75 \%$ mahasiswa nilainya di atas 66. Oleh karena itu sudah tidak diperlukan siklus berikutnya.

Tanggapan mahasiswa terhadap kegiatan pembelajaran yang dilakukan, dari 37 angket hasilnya diperoleh : rentang skor antara 45 sampai dengan 64, mean 51,38, dan simpangan baku 3,90. Hasil angket terbuka yang dirasakan mahasiswa dengan pembelajaran kooperatif model STAD adalah mayoritas mahasiswa (86,49\%) menyambut positip, Sedangkan 13,51\% menyatakan bahwa metode ini inovatif, namun justru sering mengandalkan kemampuan orang lain dari pada diri sendiri, ada yang merasa biasa saja, ada yang merasa banyak beban yang berkaitan dengan tugas. Hasil perhitungan tanggapan mahasiswa terhadap implementasi pembelajaran kooperatif STAD 10,81\% sangat setuju dan $89,19 \%$ setuju.

\section{SIMPULAN}

Pendekatan pembelajaran kooperatif model STAD dapat meningkatkan kualitas pembelajaran rangkaian listrik. Proses pembelajaran terkesan lebih menarik karena mahasiswa bukan lagi sebagai obyek tetapi lebih sebagai subyek dalam pembelajaran. Kondisi pembelajaran diwarnai dengan aktivitas diskusi kelompok, mahasiswa berperan aktif dan saling ketergantungan satu sama lain dalam penguasaan konsep sehingga terjadi interaksi belajar multi arah. Peran dosen justru sebagai fasilitator. Hasil belajar diekspresikan dalam tes mahasiswa 
mengalami peningkatan, dari rerata 67,17 siklus I menjadi 72,28 siklus II dan menjadi 74,93 pada siklus III.

Tanggapan mahasiswa terhadap implementasi pembelajaran kooperatif model STAD berdasarkan angket tertutup diperoleh hasil $10,81 \%$ mahasiswa menyatakan sangat setuju dan 89,19\% menyatakan setuju, tidak ada satupun yang menyatakan tidak setuju dan sangat tidak setuju. Angket terbuka 86,49\% yang dirasakan positip dan 13,51\% menyatakan bahwa menyatakan bahwa metode ini inovatif, namun justru sering mengandalkan kemampuan orang lain dari pada diri sendiri, ada yang merasa biasa saja, ada yang merasa banyak beban yang berkaitan dengan tugas

\section{DAFTAR RUJUKAN}

Ibrahim, Muslimin. (2000). Pembelajaran Kooperatif. Surabaya: Pusat Sains dan Matematika Sekolah Program Pasca Sarjana UNESA, University Press.

Johnson, T. Roger and Johnson.(1987).

Learning Together and Alone ;

Competitive, and Individualistic

Learning. New Jersey : Prentice Hall.

Nana Sudjana. (2002). Penilaian Hasil

Belajar Mengajar. Bandung : PT.

Remaja Rosdakarya Offset.

Pannen,P, Mustapa,D, Sekarwinahyu,M. (2001). Konstruktivisme dalam Pembelajaran. Jakarta. Proyek Pengembangan Universitas Terbuka Dirjen Dikti Depdiknas.
Slavin, R. (1994). Cooperative Learning : Theory, research and practice.

Boston : Allyn \& Bacon.

Sudarsono, FX. (2001). Apikasi Penelitian Tindakan Kelas. Jakarta. Pusat Antar Universitas Untuk Peningkatan dan Pengembangan Aktivitas Instruksional Dirjen Dikti Depdiknas. 